The Polish Journal of the Arts and Culture. New Series 7

(1/2018): 205-214 [ARTICLE]

DOI: 10.4467/24506249PJ.18.010.9784

\title{
The Kite Runner
}

\section{A'zam Rahnaward ZARYāB, translation and introduction by Khalil A. ARAB}

\begin{abstract}
About the translator
Khalil A. Arab was born in 1986 in Herat, Afghanistan. He finished his primary and secondary education in Herat. During the Taliban regime, Khalil had to quit school and worked in various jobs to help his family. Following the overthrow of the Taliban, Khalil returned to school in 2002 and finished Herāt Agriculture Vocational High School in 2004. In 2005, he was accepted by the University of Jalālābād, in which he enrolled, only to drop out following a job offer he received from the Americans. Khalil worked as an interpreter/translator for the North Atlantic Treaty Organization (NATO). In June 2010, he fled Afghanistan following a threatening letter he received from the Taliban and eventually settled in Poland as a refugee. In 2011, he enrolled at the Jagiellonian University, where he was awarded a B.A. and M.A. in Persian philology and a B.A. in American Studies. He is currently a M.A. student of American Studies and a PhD student at the Faculty of Philology. His dissertation focuses on Human-Animal Relations in Afghan Contemporary Literature.
\end{abstract}




\section{About the author}

A'zam Rahnaward Zaryāb is one of the most influential and productive Afghan fiction-writers, who had enormous influence on fiction-writing and the younger generation of writers in Afghanistan. Zaryāb was born in 1944, in Rika Khaneh district, Kabul. He was educated at the prestigious Habibiyeh School and received his B.A. in journalism from Kabul University and an M.A. in journalism in the UK. Zaryāb worked as a journalist for Žowandūn weekly as well as the Eslāh newspaper. He was also employed as Art Director at the Ministry of Information and Culture; later, he managed a periodical entitled, Aryana (Republic) Afghanistan Quarterly, which was published in English. He became editor of the newly established The Kabul Times, worked as secretary of the story section of the Afghanistan Writers' Union, and, between 1990 and 1992, was the head of the Afghanistan Writers' Association. After a while, he left for France and lived there for years. Following the American invasion of Afghanistan, he returned to his country in 2003 and briefly worked as senior advisor for the Ministry of Culture.

Zaryāb began writing stories since he was in high school. During his writing career, Zaryāb has written more than 100 short-stories and half-a-dozen novels, most of which have been published in Afghanistan and elsewhere. He has also published a number of literary articles as well as translations of works by other authors. According to Mohammadi, his translations have appeared in various media outlet under his initials (R. Z.). His translations have helped him understand fiction and fiction-writing. Besides his translations, his years of studies and living in the UK have given him an advantage over many writers of his time, an advantage he was to benefit from enormously later on during his writing career. ${ }^{1}$

Zaryāb started his writing career with a short story entitled, Flowerless and Leafless (1963), a story in which he followed the romantic tradition of his predecessors. His first attempt at writing was a promising one for a young and dynamic writer. Zaryāb's short stories can be divided into two categories. Those stories that are written before 1970 and those written after. The stories written before 1970 are realistic in style. The characters are chosen from different layers of Afghan society. ${ }^{2}$ Almost all the plots take place within a house or in a household. These are stories of families with a father who appears (most of the time, but not always) as the head of the household,

${ }^{1}$ Hossain M. Mohammadi, Tärikhe Tahliliye Dāstān Newisiye Afghanistan, Cheshmeh, Tehran 2009, pp. 201-2.

${ }^{2}$ Ibidem, pp. 203-11. 
a mother, an older brother and the narrator - a young boy or girl - who is the youngest of all. The majority of stories from this period are written in the first person. The narrator tells the story from a limited first-person point of view, only describing the events they witness. Fathers are not in the story, or, if they are around, they are aggressive, always busy, and they do not care for their family. The older brothers in these stories are always depressed, isolated, and useless tramps. Older brothers never get along with fathers. Mothers have a sublime and majestic place in Zaryāb's stories. Mothers are always kind, compassionate, and sympathetic. They always care for their families. Mothers' faces are the most familiar faces in the memories of the narrators. Wall (1963), Art Teacher (1966), Night Owl (1967), Radio (1970), Chain (1970), Evil Boy (1970) are but a few of the stories written during this period.

1970 was a productive and important year for Rahnaward Zaryāb. One can witness a dramatic shift in Zaryāb's world view published in his works in 1970, as opposed to his works published prior to $1970 .^{3}$ According to Mohammadi, the characters are no longer ordinary folks. They are replaced by lonely, isolated, and frustrated individuals, who live their lives in vain, and converse with their shadows. They live rather in their dreams and imagination. Zaryāb seems to have been hugely influenced by and admiring towards Kafka and the Iranian writer Sādeq Hedāyat (1903-1951). He even dedicated a story (from this period) to Hedāyat. ${ }^{4}$ Notes from a Rooster (1971), The YellowColoured Dog (1971), The Hen Who Died (1971), The Old Man and his Cat (1974), The Pen (1974) are but a few of many stories from this period.

Zaryāb's short stories appeared in several collections, most notably in, A Voice from Amongst Centuries (1983), Man of the Mountain (1984), Friend from a far Away City (1987), and Patterns and Thoughts (1988). A publishing house, nashre Zaryāb, has been established to honour his lifetime achievements in writing.

3 In an essay honoring Wasef Bakhtari (1942-) Zaryāb wrote that, in the 1960s, even though he was not, from the organizational perspective, a member of the People's Democratic Party of Afghanistan, he was supporting the idealogy of Parcham (banner). Parcham was one of the factions of the PDPA. Zaryāb wrote that he personally knew faction's leaders and supported faction's strategies and agendas. Zaryāb recalls that he and Bakhtari, who was a member of Faryāne Democratic Novin - New Democratic Movement, which was a Maoism movement, often argued. At the beginning of 1970 s both underwent a review of their political thinking, and questioned their political world view by placing a colossal question mark in front of them.

4 Ibidem, pp. 211-13. 
I am a kite runner. As long as I can remember, I've dealt with kites and tārr: abrasive strings. ${ }^{1}$ I wait all spring and summer long in anticipation of autumn. I can coat all types of strings in a variety of different colours: sky-blue, pink, lemon, white, and multicolour. Of course, each one of these colours are good for use at different times. For instance, when there is a dark cloud in the sky, the white string does the job better. If the cloud is light, then the lemon colours work better. And if the sky is clear, then the sky-blue is best, because the line cannot be seen and is saved from the pulleys of the kids (who are trying to pull down the kite).

Throughout our neighbourhood, the kids know me and respect me, for fear of becoming my antagonist. Sometimes, they even come and ask for my advice.

I am a kite runner, and I have the observant eyes of a kite runner. When two kites are flying too near one another on the verge of a "fight", with a single glance I can tell which kite will win the fight and which one will be cut. When there is a close fight at hand, the boys will climb on their rooftops and yell my name:

- Yaqoub, which one do you think will win?

Then, I will look at the kites, think a little, calculate everything and reply:

- That dark-red will win. - And a moment later, that is exactly what happens.

Throughout our neighbourhood, I have one competitor, and that is Hamid Totaleh: stuttering Hamid. I have to admit, this stuttering kid is no less than me. He doesn't glass-coat strings worse than I do, nor does he know fewer techniques and tricks than I do. Because we have the same power, we are at peace with one another, and we do our best not to initiate a kite-fight with one another.

Well, I am a kite runner and like everybody else, a kite runner too has an interesting story, a thing or two that has happened to him. An interesting thing happened to me four years ago.

One afternoon, someone knocked on our front-door. When I went and opened the door, I was met by a girl in a green burqa, ${ }^{2}$ who, with a hurried voice, asked me:

1 Tār or abrasive string used for fighter kites in Afghanistan, Bangladesh, India, Nepal and Pakistan. It is gummed, coloured and coated with powdered glass.

2 Burqa also known as chaduri in Afghanistan, is an outer garment worn, in mixed-gender public places, by women in Afghanistan. It covers their body and face, head-to-toe, with an embroidered screen that allows the user to see their surroundings. 
- Are you Yaqoub?

With the same hurried voice, she continued:

- I am your new neighbour. We moved to this neighbourhood recently. My little brother is sick. He's heard about you. He sent me with three spools of string to ask if you could glass-coat them for him. Will you do that?

She had a pleasant voice that I liked so much. I could see her eyes now from behind the screen of her burqa. She had dark and bright eyes. Her nose and forehead were white. To me, she seemed like a white kite with dark eyes. Her skinny, slim body made her appear taller than she actually was. I was fascinated. Then, with a certain air of frustration, she asked:

- Will you do it or not?

I pulled myself together and with bafflement answered:

- Yes, I will do it. I will do it.

Her white and shapely hand that resembled seafoam, came out from under her burqa, and she handed me three spools. Her finger nails were very red, and looked like the colour of red coral. I took the spools.

- When will they be ready? - she asked.

- The day after tomorrow - I answered. She was about to leave when I asked her:

- What colour shall they be?

She turned her face and answered:

- Can they be multi-coral?

I asked her again:

- Are you saying they should be multi-coloured?

She chuckled sweetly and said:

- Yes. I cannot pronounce this word correctly. Ever since I was a little girl, I've always mispronounced it, good bye.

She left, and until I saw her for the second time, her last sentence was ringing in my ears - "Since I was a little girl, I've always pronounced it multicoral, good bye".

During those two days, her white nose and forehead, and her dark and bright eyes, that looked like a white kite with two black little eyes, were not going away from my mind. A kind of unknown delight tickled my heart, time and again, and I wanted to whisper repeatedly, "Our new neighbour".

And, when I saw my mother, I screamed:

- What a great neighbour we've found!

- Do you know them? - my mother asked coldly. 
- Yes, I know them - I answered.

In those two days, I employed all my strength. I did not withhold any materials I knew were necessary for proper glass-coating. Finally, the lines were ready, and she came once again. She wore the same burqa and had the same dark and bright eyes. I saw her white nose and forehead once again and heard her pleasant voice, when she asked me:

- Did you coat the strings?

- Yes, I did - I replied. And, while I was demonstrating the sharpness of the lines to her, I continued:

- A combination of sky-blue and white.

- How is that? Is that a good colour? - she asked.

- This line is very good when the weather is cloudy - I answered.

When she witnessed the sharpness of the lines, she made a noise that was filled with excitement. She almost snatched the spool from my hand and asked:

- How much shall I pay?

Without answering her question, I added:

- This winder ${ }^{3}$ you are holding is made of shisham, north-Indian rosewood. It is as solid as steel. Even if it falls from the rooftop, it won't break.

She cut me off and, with the irritated voice of her first-day meeting, asked: - How much shall I pay?

From this question, a kind of embarrassment ran throughout my entire body. I finally replied.

- What are you saying, how I could take money from my neighbour?

- That means you are not taking any money? - she asked.

I shook my head side-to-side.

She examined me head to toe, and, like on the first day, she chuckled a sweet chuckle and said:

- Well, then good bye.

She left. The delight tickled my heart, even more this time.

3 The uncoated strings are, as is usual, rolled on a wooden-spool. Most kite enthusiasts in Afghanistan roll their strings over a winder called a charkheh (literally means spinner). A charkheh - winder - is used for more comfortable handling of the strings and faster winding and unwinding, once the kite is ready to be flown. The abrasive string or $t \bar{a} r$, however, comes with a charkheh. In the story, it is safe to assume that the narrator rolled the strings once he glass-coated them, on a special charkheh, one of his own making, and presented it to the girl. To see a photo of a winder, click here. 
- Our new neighbour - I murmured. And I went inside the house, found my mother once again and said:

- What a great neighbour we've found!

She asked me in a colder and more uninterested manner. - Do you know them?

With an air of pride, I almost screamed my answer:

- Yes, I know them.

The next morning, I was on our rooftop observing the flying kites. Hamid Totaleh was flying his kite and he had remained unchallenged. His kite was a three-foot blue colour piece with a white tail that was roaring like a dragon, attacking at every direction and no one could offer any resistance. All other kite owners wanted to keep a distance from his kite. Many people landed their kites.

Suddenly, I saw a kite was being launched from our new neighbour's rooftop, a three-foot white-coloured kite with a blue tail and a pair of blue eyes. I thought about the girl, and the same delight tickled me again - "Our new neighbour".

I ran towards their roof. It was fortified with $s a n j^{4}$ stones. I couldn't see the kite's owner. I was nervous. I wanted to see the quality of my glasscoating. The kite soared, flew high and higher; suddenly, I saw it rush towards the three-foot blue colour kite with a white tail; it rushed towards Hamid Totaleh's kite. My body began trembling. By the time I wanted to scream with all my might and advise against going that direction, it was already too late; the two lines were tangled together. Then, a sense of weakness took over me and my body, a sense of indolence. I was certain that our new neighbour, this little sick kid, would be cut instantly and disappear like smoke in the air. Then, I would never be able to look into the girl's eyes again. I knew that having nice abrasive string is not good enough to cut another kite; it required expertise, a combination of skills and experience, both of which Hamid Totaleh had enough of at his disposal.

I came out of my thoughts only when the two kites had already gone far away. I realized that the fight took much longer. Hope was sprouting inside me, when I realized that our new neighbour was not inexperienced. I thought to myself: "Our new neighbour is a good kite fighter. I don't know why he sent his strings to me, to glass-coat them".

4 A black stone native to the Indian subcontinent. One of the characteristics of the stone is, besides being shiny, it is easy to break, and hence shape it for various uses. 
By now, both kites looked very small. Hamid Totaleh's three-foot kite was going forward in a flat straight motion, and our neighbour's kite was yawing away. Suddenly, I saw our neighbour playing out the line, the kite was getting lower and lower as if it was about to land on a rooftop in the distance. I held my hands around my mouth and shouted:

- Don't spin it, keep it still.

But the kite was yawing and yawing and was going lower every single moment. It seemed that our neighbour did not hear me shouting. I said to myself, "It seems that this sick little kid is deaf too".

Then I climbed up the wall hurriedly. I ran across the first rooftop. I climbed up on our new neighbour's sanj wall. My eyes caught the sight of our new neighbour's rooftop. I was frozen with astonishment. On the rooftop, I saw the girl standing, holding the winder in her left hand and the kite's string in her right hand. Her hair was unkempt. She looked anxious and upset. Her back was towards me, so I shouted:

- Hold it still already!

Without any sign of apprehension regarding my sudden appearance, she said:

- I can't. Come and do it yourself.

I climbed down the wall and, with a lot of effort, pulled up the kite. The kite started going up slowly, and then suddenly I saw the three-foot blue kite was going down with a twisting motion. A sudden hum was heard from the rooftops, the girl shouted with joy and delight:

- I cut it.

Then, she danced round and round and raised her hands in the air and screamed:

- Long live!

An old woman shouted from the yard:

- Zainab! What is happening?

The girl leaned over the roof fences and said:

- Mother, I cut Hamid Totaleh.

- Oh! You evil girl! - The old woman replied.

From that day on, the story of our news filled the entire neighbourhood. Everyone talked about this new kid, whom no one had seen, who cut Hamid Totaleh. At first, everyone said:

- He cut Hamid Totaleh after they let out three spools of string. Then, they said: 
- After they let out the first spool, he cut Hamid Totaleh.

Finally, they all swore and said:

- I swear to God that he cut Hamid Totaleh like a knife cuts cheese.

Several days had passed from that incident. One day, I was on our roof. My kite was up in the sky, flying around. All of a sudden, I saw a three-foot white kite, only this time with a black tail and black eyes, had been launched from our neighbour's rooftop. It ascended, and, in a blink of an eye, I saw it flying right next to my kite, intending to fight my kite. I couldn't run away, because I could have lost all my credibility. Anger ran through my body, and I murmured under my lips:

- You foolish girl!

The fight had already broken out. I knew that when the strings are of the same quality, it is experience that plays the decisive role. Therefore, I was certain that with my experience I would beat our new neighbour. She let out line in the first three minutes, and then she fought as if she had had twenty years of experience fighting kites.

Anger and fear were accumulating in my heart every single moment. Bystanding boys had placed their hands on their foreheads, shielding their eyes from the sunlight and, with much interest and excitement, watched our kites fighting. My heart was racing. Our kites were yawing away. In the absence of strong wind, our kites went horizontally. Our lines were dropping lower and lower every moment, and the kites were descending, getting closer and closer to the rooftops.

- It's enough already... pull up your kite! - I shouted. No answer. Instead, I heard the sly laugh of a girl. Still, I started winding the line and pulling the kite upward. My kite started rising slowly. I was hoping our new neighbour would wind down her kite, but instead she continued unwinding the line, and then she sped up. Enraged, once again I yelled:

- Pull it up!

Between waves of trembling rage, I felt my line tension released, followed by the sudden astounding uproar from bystanders:

- Wow!

I was cut. I let the string go. I came across the roof, climbed up the stone wall, my intention was to throw every insult I knew at the girl. When I climbed up the wall, once again I was astonished by what I had witnessed. My legs were crumbling and my mouth was dry, because I saw Hamid Totaleh holding the line and the girl was dancing around. 
Then, the old woman's voice was heard from the yard:

- Zainab! What is going on?

The girl leaned over the fences once again and said:

- Mother, I cut Yaqoub.

The old woman was heard again saying:

- Oh! You evil girl!

While slowly winding down the kite, without paying any attention to the girl's jubilation, Hamid Totaleh said:

- When... you... your rival is... pulling down their k... kite, le... let them do that. Y... you un... unwind your line, an... and do it fast and fas t... faster. 